\title{
The association of leptin with dyslipidemia, arterial hypertension and obesity in Kyrgyz (Central Asian nation) population
}

\author{
Erkin M Mirrakhimov ${ }^{1,2,3^{*}}$, Alina S Kerimkulova ${ }^{1}$ Olga S Lunegova ${ }^{2}$, Aibek E Mirrakhimov ${ }^{1}$, Malik P Nabiev ${ }^{1}$, \\ Kseniya V Neronova' ${ }^{1}$, Asiyat A Bayramukova ${ }^{1}$, Nazira T Alibaeva ${ }^{3}$ and Nurdin Satarov ${ }^{1}$
}

\begin{abstract}
Background: Leptin, an adipocytokine produced by adipose tissue, along with the traditional cardiometabolic risk factors, contributes to the development of cardiovascular complications. At the same time, ethnic features of adipocytokines have been insufficiently investigated, especially among Asians, who have an increased risk of cardiovascular complications compared with Europeans. Aim of study was to investigate the relationship between leptin levels and age, gender, anthropometric parameters, lipid parameters, arterial hypertension (AH), and obesity in the adult population of ethnic Kyrgyz people living in Central Asia.

Results: In total, 322 ethnic Kyrgyz (145 men, 177 women) aged $\geq 30$ years were studied. Waist and hip circumference, body mass index, blood glucose, lipids, leptin, and homeostatic model assessment were measured. Patients in the upper quartile of leptin levels had high values of BMI, WC, systolic and diastolic blood pressure, glucose, and HOMA index compared with patients with lower leptin levels. The prevalence of metabolic syndrome and $\mathrm{AH}$ increased with higher levels of leptin. Leptin positively correlated with BMI, WC, triglycerides, and glucose concentrations in patients of both sexes. According to the multivariate logistic regression analysis, elevated leptin levels increased by 30 times the risk of obesity in men, regardless of the presence of type 2 diabetes, and 17.7 times in women.
\end{abstract}

Conclusion: Leptin is associated with general and abdominal obesity, dyslipidemia, and insulin resistance in Kyrgyz patients.

Keywords: Leptin, Abdominal obesity, Dyslipidemia, Arterial hypertension

\section{Background}

High global prevalence of cardiometabolic diseases and the related mortality stimulated research focused on the risk factors, one of which is obesity [1-3]. It is well known that overweight and obese individuals have higher general as well as cardiac mortality [4]. Furthermore, obesity is strongly associated with the development of arterial hypertension ( $\mathrm{AH})$, insulin resistance (IR), type 2 diabetes mellitus (DM), atherogenic dyslipidemia, and other diseases [5].

\footnotetext{
* Correspondence: ermir@infotel.kg

${ }^{1}$ Kyrgyz State Medical Academy named by I.K. Akhunbaev, Akhunbaev street 92, Bishkek 720020, Kyrgyzstan

${ }^{2}$ National Centre of Cardiology and Internal medicine named by M. Mirrakhimov, Togolok Moldo 3, Bishkek 720040, Kyrgyzstan

${ }^{3}$ Kyrgyz-Russian (Slavic University), Kievskaya 44, Bishkek 720040, Kyrgyzstan
}

The association between obesity and cardiometabolic risk factors may be mediated by the ability of adipocytes to synthesize biologically active substances with hormonal activity [6]. One of these hormones is leptin, which was identified in 1994 and has attracted the attention of obesity researchers [7]. Leptin is a 167 amino acid protein encoded by the obesity $(\mathrm{OB})$ gene and is synthesized and secreted by adipocytes. In this case, serum leptin concentrations reflect the amount of energy reserves stored in adipose tissue [8]. In addition, leptin plays an important role in the regulation of feeding behavior and is closely associated with body mass index (BMI) and AH [9]. Leptin was shown to be associated with IR and other cardiometabolic risk factors in certain populations [10-12]. 
At the same time, obesity has been reported to have a different impact on metabolic risk factors and development of cardiovascular diseases in different ethnic groups [13]. It was also shown that among Asians, compared with Europeans, there is a higher incidence of coronary heart disease (CHD) [14]. In addition, cardiometabolic risk factors such as type $2 \mathrm{DM}, \mathrm{IR}$, and abdominal obesity are often identified among Asians [15-17]. This raises the question of whether ethnicity influences the prevalence of cardiometabolic risk factors and cardiovascular disease, which has not been sufficiently studied.

Levels of leptin have never been studied in the ethnic Kyrgyz population. The purpose of this study was to investigate the relationship between leptin levels and age, gender, and anthropometric and lipid parameters in ethnic Kyrgyz adults.

\section{Methods}

\section{Subjects}

In 2008, we conducted a pilot cross-sectional study assessing the prevalence of cardiometabolic risk factors among residents of Kyrgyzstan. That study included 956 subjects who were later enrolled in the current investigation.

Exclusion criteria were age $<35$ and $>70$ years, conditions that could potentially alter leptin concentrations such as prolonged fasting, surgery within 1 month from study enrollment, advanced chronic diseases (such as chronic liver disease, chronic kidney disease, systemic autoimmune disease, congestive heart failure, thyroid disease, etc.), chronic use of glucocorticosteroids, use of lipid-lowering medications, patients with DM using insulin, pregnancy and lactation, chronic alcohol abuse, and people not of a Kyrgyz ethnic background. Thus, we included 322 ethnic Kyrgyz (145 men, 177 women), who signed informed consent to participate in the study, which included taking blood samples that were sent to France for analyses. The study protocol was approved by the local Ethical Committee of the National Center of Cardiology and Internal medicine, named after M.M. Mirrakhimov.

\section{Clinical examinations and laboratory analysis}

All participants were examined by a cardiologist. The examination included taking the presenting complaints, medical history, physical examination with measurement of anthropometric parameters (height, weight, waist circumference [WC], hip circumference [HC], and blood pressure $[\mathrm{BP}])$. BMI was calculated using the following formula: $\mathrm{BMI}=$ weight $(\mathrm{kg}) /$ height $(\mathrm{m})^{2}$. Obesity was considered as a BMI $\geq 30 \mathrm{~kg} / \mathrm{m}^{2}$ and overweight as a BMI of $25-29.9 \mathrm{~kg} / \mathrm{m}^{2}$ [18]. IR was calculated using the HOMA index values with the following formula: HOMA = serum insulin $(\mu \mathrm{IU} / \mathrm{ml}) \times$ plasma sugar $(\mathrm{mmol} / \mathrm{L}) / 22.5$. A value of $\geq 2.77$ was considered to be diagnostic for IR. Metabolic syndrome (MS) was defined according to modified
ATP-III criteria [19]. All included patients filled out the Finnish Diabetes Association questionnaire to assess the risk of developing DM [20], which included information on vegetable consumption (every day or not every day) and physical activity (more or less than 30 minutes per day).

Blood samples were taken as previously described [21]. Laboratory tests included blood glucose (fasting), lipid profile (total cholesterol [TC], triglycerides [TG], high-density lipoprotein cholesterol [HDL-C], and lowdensity lipoprotein cholesterol [LDL-C]). All biochemical analyses were carried out in Dir adjoint du département Hommes, Natures, Muséede l'Homme (Paris, France). Leptin was determined using solid-phase enzyme immunoassay (EIA), and insulin by the enzyme-linked immunosorbent assay (ELISA)method (Bayer Corp). LDL-C was calculated by the Friedwald formula [22].

\section{Statistics}

Statistical analysis was performed using SPSS 17.0 for Windows (SPSS, Inc., Chicago, IL). Variables with a normal distribution are presented as mean \pm standard deviation and those with a nonparametric distribution as median $\left(25^{\text {th }}\right.$ and $75^{\text {th }}$ percentiles). The relationship between leptin and cardiometabolic risk factors was examined using Spearman rank order correlation. Analysis of variance (ANOVA) according to the Kruskal-Wallis method was used to compare the values (given the nonparametric distribution of variables). Post-hoc comparisons were performed by the Mann-Whitney test. Multivariate logistic regression analysis with stepwise inclusion of the variables was performed to identify the main factors influencing the development of obesity in the study group. Serum leptin concentrations were transformed into a natural logarithm to normalize the asymmetric distribution. A p-value $<0.05$ was considered to be statistically significant.

\section{Results}

\section{Clinical characteristics}

Clinical characteristics of the patients enrolled in the study are presented in Table 1. The mean age was $51.7 \pm$ 9.6 years. The prevalence of major cardiovascular risk factors (obesity, abdominal obesity, type 2 DM, smoking, and hyperlipidemia) was consistent with their prevalence in the sample from the primary study that was conducted in 2008 (please see the subjects section). However, the prevalence of $\mathrm{AH}$ was higher in the current sample (41.9\%) compared with the initial group (36.2\%). Nevertheless, systolic and diastolic BP were comparable in the two populations.

For evaluation of the association between leptin levels and cardiometabolic risk factors, all participants in the study were stratified into four groups based on quartiles of leptin $(<2.2,2.2-4.2,4.3-6.34,>6.34 \mathrm{ng} / \mathrm{ml}$ for males; < 8.05, 8.05-13.4, 13.5-19.09, > $19.09 \mathrm{ng} / \mathrm{mL}$ for 
Table 1 Clinical characteristics of patients

\begin{tabular}{ll}
\hline & $\mathbf{n}=\mathbf{3 2 2}$ \\
\hline Age, years & $51,7 \pm 9,6$ \\
Male, $\mathrm{n}(\%)$ & $145(45)$ \\
Obesity, $\mathrm{n}(\%)$ & $94(29,2)$ \\
BMl, kg/m & $27,4 \pm 4,8$ \\
AO, $\mathrm{n}(\%)$ & $136(42,2)$ \\
WC, cm & $91,2 \pm 11,5$ \\
HC, cm & $101,4 \pm 10,3$ \\
WC/HC & $0,9 \pm 0,08$ \\
AH, n (\%) & $135(41,9)$ \\
SBP, mm Hg & $135 \pm 22$ \\
DBP, mm Hg & $85 \pm 12$ \\
Type 2 DM, n (\%) & $22(6,8)$ \\
Fasting glucose, mmol/l & $5,48(5,1 ; 5,9)$ \\
TC, mmol/l & $5,1 \pm 1,1$ \\
HDL-C, mmol/l & $1,1 \pm 0,3$ \\
LDL-C, mmol/l & $3,2 \pm 0,9$ \\
TG, mmol/l & $1,2(0,9 ; 1,9)$ \\
MC, n (\%) & $107(33,2)$ \\
Leptin, ng/ml & $7,8(4,0 ; 14,7)$ \\
\hline
\end{tabular}

females). As shown in Table 2, comparative analysis of the groups showed a significant difference in the age of the men: participants in the in the $4^{\text {th }}$ quartile were younger $(p=0.02)$. At the same time, it was observed that patients in the upper quartile of leptin had high values of BMI, WC, systolic BP and diastolic BP, glucose, and HOMA index compared with patients with lower leptin levels. The prevalence of MS and $\mathrm{AH}$ increased with higher levels of leptin. The above-described pattern was observed for the women as well, although the age was comparable in the groups of women. In addition, in contrast to the men, the groups of women showed no significant difference in TC, TG, LDL-C, as well as the occurrence of type 2 DM. The last was obviously due to the small number of patients with diabetes (Table 2).

To study the association of leptin levels with BMI, patients were stratified into three groups: normal weight $\left(\mathrm{BMI}<25 \mathrm{~kg} / \mathrm{m}^{2}\right)$; overweight $\left(\mathrm{BMI} \geq 25-29.9 \mathrm{~kg} / \mathrm{m}^{2}\right)$; and obese $\left(B M I \geq 30 \mathrm{~kg} / \mathrm{m}^{2}\right)$. Comparative analysis revealed elevated leptin concentrations in men and women with increasing BMI ( $<<0.001$; Table 3).

Next, we calculated Spearman correlation coefficients for leptin and anthropometric parameters, lipid profile, and blood sugar levels in men and women (Table 4). Leptin positively correlated with BMI, WC, TG, and glucose concentrations in patients of both sexes. At the same time, leptin was positively correlated with $\mathrm{TC}$ in men, and negatively correlated with HDL-C in women (Table 4).
Multivariate logistic regression analysis was performed to assess the impact of various factors on the development of obesity and cardiovascular risk factors. Several regression models were analyzed, with the presence of obesity, AH, IR, DM as dependent variables and factors that may have an impact on their development (leptin, HDL-C, age, BMI, DM, AH, physical activity [more than 30 or less than 30 minutes a day] and vegetable consumption [every day or not every day]) as independent variables.

According to the analysis, elevated leptin levels increased by 30 times the risk of obesity in men, regardless of the presence of DM, and 17.7 times in women. In addition, physical activity of less than 30 minutes a day in women increased the risk of obesity by 3.2 times. A similar regression model constructed for $\mathrm{AH}$ showed that leptin levels increased by 2.1 times the risk of hypertension in men $(\mathrm{p}=0.003$; odds ratio [OR] 2.1; confidence interval $[\mathrm{CI}] 1.3-3.6)$ and in women $(\mathrm{p}=0.01$; OR 1.75; CI 1.2-3.8). However, an interconnected influence of leptin was lost after adjustment for BMI as an independent variable in the regression equation, probably due to obesity. Elevated levels of leptin also increased by 4.3 times the risk of IR in men and 6.9 times in women, regardless of BMI. The regression model for DM showed a trend for statistical significance (Table 5).

\section{Discussion}

Unequal prevalence of cardiovascular disease in different ethnic groups is characterized by greater occurrence of cardiometabolic risk factors among Asians compared with Europeans [14]. Indeed, type 2 DM, IR, and abdominal obesity are frequently detected among Asians [15-17]. However, the available scientific publications are based mainly on research among South Asians [14-17]. Kyrgyz are people living in Central Asia, mainly in the highlands, with a different ancestral origin. Extrapolation of the results of the above-mentioned studies to the Kyrgyz ethnic group is not entirely correct, because there are significant differences between geographical living conditions and nutritional factors in the Kyrgyz compared with residents of South Asia (southern India, Pakistan, and Bangladesh).

In the present study, serum leptin concentrations were 3.1 times higher in women than in men. Similar sexual dimorphism was found in other studies (the difference ranged from 2.35 to 4.8 times) [23,24]. Gender differences in serum leptin concentrations are apparently due to several factors: the high content of fat in women [25-27]; structural differences in the hypothalamus [27]; and the influence of sex hormones. It is thought that androgens have a suppressive effect on leptin concentrations [27]. In addition, gender differences in leptin concentrations may also be affected by differences in body fat distribution. Central fat distribution is more common in men and peripheral fat distribution in women [28]. WC and $\mathrm{HC}$ are 
Table 2 Characteristics of patients in association with leptin level*

\begin{tabular}{|c|c|c|c|c|c|}
\hline Men & 1 quartile $n=39$ & 2 quartile $n=35$ & 3 quartile $n=35$ & 4 quartile $n=36$ & $p$ \\
\hline Age, years & $52,5 \pm 10,8$ & $56,6 \pm 9,6$ & $55 \pm 9,6$ & $50,3 \pm 8,5^{\dagger}$ & 0,02 \\
\hline BMl kg/m² & $22,9 \pm 2,3$ & $25,5 \pm 2,5^{\# \#}$ & $27,7 \pm 2,2^{\# \#+}$ & $29,8 \pm 4,1^{\# \#++\S}$ & 0,0001 \\
\hline$W C, \mathrm{~cm}$ & $83,7 \pm 8,1$ & $92,7 \pm 7,2^{\# \#}$ & $98,9 \pm 6,6^{\# \#+}$ & $102,1 \pm 11,6^{\# \#++}$ & 0,0001 \\
\hline $\mathrm{AH}, \mathrm{n}(\%)$ & $12(30,8)$ & $15(42,9)^{\#}$ & $17(48,6)^{\#}$ & $23(63,9)^{\# \#}$ & 0,0004 \\
\hline $\mathrm{SBP}, \mathrm{mm} \mathrm{Hg}$ & $126 \pm 18$ & $139 \pm 20^{\#}$ & $139 \pm 20^{\#}$ & $148 \pm 23^{\# \#}$ & 0,0001 \\
\hline $\mathrm{DBP}, \mathrm{mm} \mathrm{Hg}$ & $80 \pm 12$ & $84 \pm 10$ & $90 \pm 12^{\#+}$ & $95 \pm 14^{\# \#+\dagger}$ & 0,0001 \\
\hline $\mathrm{TC}, \mathrm{mmol} / \mathrm{l}$ & $4,7 \pm 0,9$ & $5,3 \pm 1,3$ & $5,7 \pm 1,1^{\#}$ & $5,2 \pm 1,03$ & 0,004 \\
\hline $\mathrm{TG}, \mathrm{mmol} / \mathrm{l}$ & $1,1(0,8 ; 1,5)$ & $1,8(1,2 ; 2,4)^{\# \#}$ & $1,5(1,2 ; 2,6)^{\# \#}$ & $1,7(1,2 ; 2,4)^{\# \#}$ & 0,000 \\
\hline $\mathrm{HDL}-\mathrm{C}, \mathrm{mmol} / \mathrm{l}$ & $1,13 \pm 0,4$ & $0,9 \pm 0,3$ & $1,0 \pm 0,3$ & $1,05 \pm 0,3$ & 0,4 \\
\hline LDL-C, mmol/l & $3,04 \pm 0,8$ & $3,4 \pm 1,3$ & $3,8 \pm 1,04^{\#}$ & $3,3 \pm 0,8$ & 0,03 \\
\hline Type 2 DM, n (\%) & $0(0)$ & $4(11,4)$ & $6(17,1)$ & $4(11,1)$ & 0,08 \\
\hline Fasting glucose, mmol/l & $5,3(4,9 ; 5,7)$ & $5,5(5,2 ; 6,1)$ & $5,6(5,3 ; 6,5)^{\#}$ & $5,7(5,2 ; 6,5)^{\#}$ & 0,046 \\
\hline HOMA index & $0,9(0,6 ; 1,2)$ & $1,5(1,2 ; 2,2)^{\# \#}$ & $2,3(1,6 ; 3,1)^{\# \#+}$ & $3,2(2,2 ; 4,5)^{\# \#++\S}$ & 0,0001 \\
\hline MS, \% & 15,4 & 25,7 & $37,1^{\#}$ & $55,6^{\# \#+}$ & 0,0005 \\
\hline Women & $n=44$ & $n=45$ & $n=44$ & $n=44$ & \\
\hline Age, years & $49,1 \pm 11,1$ & $49,8 \pm 8,9$ & $51,6 \pm 8,9$ & $50,6 \pm 7,2$ & 0,5 \\
\hline BMl kg/m² & $23,6 \pm 3,8$ & $26,8 \pm 2,8^{\# \#}$ & $29,5 \pm 3,6^{\# \#+}$ & $33,3 \pm 5,2^{\# \#++\S \S}$ & 0,0001 \\
\hline$W C, \mathrm{~cm}$ & $78,7 \pm 9,5$ & $87,4 \pm 8,0^{\# \#}$ & $92,1 \pm 8,7^{\# \#+}$ & $97,5 \pm 9,9^{\# \#++\S}$ & 0,0001 \\
\hline $\mathrm{AH}, \mathrm{n}(\%)$ & $11(25)$ & $13(29,5)$ & $23(51,1)^{\#}$ & $20(45,5)$ & 0,01 \\
\hline $\mathrm{SBP}, \mathrm{mm} \mathrm{Hg}$ & $127 \pm 20$ & $128 \pm 21$ & $140 \pm 23^{\# \#+}$ & $136 \pm 19^{\dagger}$ & 0,001 \\
\hline $\mathrm{DBP}, \mathrm{mm} \mathrm{Hg}$ & $81 \pm 10$ & $82 \pm 11$ & $88 \pm 12^{\# \# \dagger}$ & $86 \pm 11$ & 0,003 \\
\hline $\mathrm{TC}, \mathrm{mmol} / \mathrm{l}$ & $4,8 \pm 1,1$ & $5,0 \pm 0,9$ & $5,1 \pm 1,2$ & $4,9 \pm 0,9$ & 0,7 \\
\hline $\mathrm{TG}, \mathrm{mmol} / \mathrm{l}$ & $0,9(0,7 ; 1,3)$ & $1,2(0,9 ; 1,4)$ & $1,2(0,9 ; 1,8)^{\#}$ & $1,1(1,0 ; 1,5)^{\#}$ & 0,05 \\
\hline $\mathrm{HDL}-\mathrm{C}, \mathrm{mmol} / \mathrm{l}$ & $1,3 \pm 0,4$ & $1,2 \pm 0,3$ & $1,1 \pm 0,3$ & $1,2 \pm 0,3$ & 0,2 \\
\hline LDL-C, mmol/l & $2,9 \pm 0,9$ & $3,2 \pm 0,9$ & $3,2 \pm 1,0$ & $3,2 \pm 0,8$ & 0,5 \\
\hline Type 2 DM, n (\%) & $3(6,8)$ & $3(6,8)$ & $1(2,2)$ & $1(2,3)$ & 0,5 \\
\hline Fasting glucose, mmol// & $5,2(4,9 ; 5,5)$ & $5,5(5,1 ; 5,8)^{\#}$ & $5,5(5,2 ; 6,3)^{\#}$ & $5,6(5,3 ; 6,0)^{\# \#}$ & 0,001 \\
\hline HOMA index & $0,9(0,8 ; 1,4)$ & $1,8(1,4 ; 2,6)^{\# \#}$ & $2,3(1,6 ; 3,6)^{\# \#}$ & $2,7(2,1 ; 4,0)^{\# \#+\dagger}$ & 0,0001 \\
\hline MS, \% & 15,9 & 17,8 & $50^{\# \#+}$ & $50^{\# \#+}$ & 0,00005 \\
\hline
\end{tabular}

*- quartile of leptine: men $(<2,2 ; 2,2-4,2 ; 4,3-6,34 ;>6,34)$, women $(<8,05 ; 8,05-13,4 ; 13,5-19,09 ; 19,09)$.

${ }^{\#}-\mathrm{p}<0,05 ;{ }^{\# \#}-\mathrm{p}<0,001$ compared to the first quartile.

${ }^{\dagger}-p<0,05 ;{ }^{t+}-p<0,001$ compared to the second quartile.

§ $\mathrm{p}<0,05 ;{ }^{\S \S}-\mathrm{p}<0,001$ compared to the third quartile.

indicators of central and peripheral obesity, respectively [28]. Different studies revealed an association between leptin and regional adiposity. Leptin is more dependent on subcutaneous adipose tissue than on abdominal visceral tissue [29], since subcutaneous adipocytes secrete more leptin than omental fat tissue [30]. Studies have shown

Table 3 Leptin levels and BMI

\begin{tabular}{lllll}
\hline BMI $\mathbf{~ g g} / \mathbf{m}^{\mathbf{2}}$ & $\mathbf{n}$ & Men $(\mathbf{n}=\mathbf{1 4 5})$ & $\mathbf{n}$ & Women $(\mathbf{n}=\mathbf{1 7 7})$ \\
\hline$<25$ & 47 & $2,0(1,4 ; 3,5)$ & 45 & $6,3(3,9 ; 8,5)$ \\
$25-29,9$ & 71 & $4,8(3,2 ; 6,2)$ & 65 & $13,3(10,5 ; 17,2)$ \\
$\geq 30$ & 27 & $8,0(5,7 ; 12,7)^{*}$ & 67 & $18,87(15,7 ; 24,7)^{*}$ \\
\hline
\end{tabular}

$*_{-} p<0,001$. higher subcutaneous fat content in women than in men [31-33]. It is known that leptin levels reflect the amount of adipose tissue in the body, and hyperleptinemia is common in general and abdominal obesity. Similar results were obtained in the present study: serum leptin levels were significantly associated with abdominal obesity (AO), hypertriglyceridemia, and hyperglycemia. In addition, serum leptin levels positively correlated with BMI in patients of both sexes, although women had a higher BMI. The results of research on the relationship between serum leptin and lipids showed conflicting data. Some studies revealed no relationship between leptin and the parameters of a lipid profile $[34,35]$. Other studies showed a significant positive correlation between leptin and HDL-C [36,37] and 
Table 4 The Spearman correlation coefficient between leptin and independent factors

\begin{tabular}{|c|c|c|c|c|}
\hline & \multicolumn{2}{|l|}{ Men } & \multicolumn{2}{|c|}{ Women } \\
\hline & $r$ & $P$ & $r$ & $p$ \\
\hline Age & $-0,063$ & 0,45 & 0,127 & 0,09 \\
\hline BMl kg/m² & 0,719 & 0,000 & 0,74 & 0,000 \\
\hline$W C, \mathrm{~cm}$ & 0,684 & 0,000 & 0,649 & 0,000 \\
\hline $\mathrm{HC}, \mathrm{cm}$ & 0,659 & 0,000 & 0,621 & 0,000 \\
\hline $\mathrm{WC} / \mathrm{HC}$ & 0,341 & 0,000 & 0,243 & 0,001 \\
\hline $\mathrm{TC}, \mathrm{mmol} / \mathrm{l}$ & 0,214 & 0,01 & 0,09 & 0,235 \\
\hline $\mathrm{TG}, \mathrm{mmol} / \mathrm{l}$ & 0,301 & 0,000 & 0,194 & 0,01 \\
\hline $\mathrm{HDL}-\mathrm{C}, \mathrm{mmol} / \mathrm{l}$ & $-0,079$ & 0,3 & $-0,156$ & 0,04 \\
\hline LDL-C, mmol/l & 0,163 & 0,05 & 0,126 & 0,09 \\
\hline Fasting glucose, $\mathrm{mmol} / \mathrm{l}$ & 0,256 & 0,002 & 0,306 & 0,000 \\
\hline
\end{tabular}

TG [38]. In the present study, we found a positive correlation of leptin with TC in men and a weak negative correlation with HDL-C in women, probably due to the higher prevalence of hypercholesterolemia and decreased HDL-C in men and in women, respectively. At the same time, leptin levels were significantly correlated with TG in patients of both sexes. TG is stored in adipose tissue as the main form of energy among the biochemical markers, which explains its correlation with leptin [39-41].

In our study, we found an association of leptin with $\mathrm{AH}$, which was confirmed in other studies such as the Olivetti Heart Study [42]. The prehypertensive effect of leptin was also shown in experimental animal research [43-46]. Apparently, such a relationship of leptin with $\mathrm{AH}$ is associated with the sympathetic nervous system, and its activation accompanies obesity in humans $[47,48]$. In our study,

Table 5 Results of logistic regression models with stepwise inclusion of the variables: obesity, AH, IR и DM

\begin{tabular}{|c|c|c|c|c|}
\hline & B & $\mathrm{p}$ & Expected $B$ & $95 \% \mathrm{Cl}$ expected $\mathrm{B}$ \\
\hline \multicolumn{5}{|c|}{ Dependent - obesity } \\
\hline \multicolumn{5}{|l|}{ Men: } \\
\hline Leptin & 3,43 & 0,000 & 30,8 & $7,3-129,6$ \\
\hline HDL-cholesterol & $-3,48$ & 0,007 & 0,031 & $0,002-0,39$ \\
\hline $\mathrm{DM}$ & $-2,097$ & 0,07 & 0,123 & $0,03-1,21$ \\
\hline \multicolumn{5}{|l|}{ Women: } \\
\hline Leptin & 2,87 & 0,000 & 17,71 & $6,64-47,2$ \\
\hline HDL-cholesterol & $-1,41$ & 0,03 & 0,24 & $0,07-0,87$ \\
\hline Low physical activity* & 1,15 & 0,02 & 3,17 & $1,18-8,54$ \\
\hline \multicolumn{5}{|c|}{ Dependent - AH } \\
\hline \multicolumn{5}{|l|}{ Men: } \\
\hline Age & 0,053 & 0,008 & 1,054 & $1,01-1,096$ \\
\hline $\mathrm{BMI}$ & 0,217 & 0,000 & 1,24 & $1,12-1,38$ \\
\hline \multicolumn{5}{|l|}{ Women: } \\
\hline Low physical activity* & 1,094 & 0,019 & 2,99 & $1,2-7,44$ \\
\hline Age & 0,093 & 0,000 & 1,097 & $1,05-1,15$ \\
\hline $\mathrm{BMI}$ & 0,11 & 0,003 & 1,12 & $1,04-1,2$ \\
\hline \multicolumn{5}{|c|}{ Dependent- IR } \\
\hline \multicolumn{5}{|l|}{ Men: } \\
\hline Leptin & 1,45 & 0,000 & 4,25 & $2,14-8,43$ \\
\hline HDL-cholesterol & $-2,34$ & 0,006 & 0,096 & $0,02-0,51$ \\
\hline Low physical activity* & 1,43 & 0,003 & 4,2 & $1,64-10,7$ \\
\hline \multicolumn{5}{|l|}{ Women: } \\
\hline Leptin & 1,93 & 0,000 & 6,87 & $2,96-15,96$ \\
\hline HDL-cholesterol & $-3,18$ & 0,000 & 0,042 & $0,01-0,2$ \\
\hline \multicolumn{5}{|c|}{ Dependent - DM } \\
\hline \multicolumn{5}{|l|}{ Men: } \\
\hline $\mathrm{AH}$ & 1,41 & 0,041 & 4,09 & $1,06-15,82$ \\
\hline \multicolumn{5}{|l|}{ Women: } \\
\hline $\mathrm{AH}$ & 1,64 & 0,049 & 5,16 & $1,01-26,4$ \\
\hline
\end{tabular}

*Low physical activity - less than 30 min a day. 
the logistic regression analysis revealed an association of leptinemia and $\mathrm{AH}$, which disappeared after adjustment for BMI as an independent variable, indicating a relationship with obesity. Indeed, the physiological influence of leptin is shown in weight loss as reduced appetite and increased energy expenditure, as a result of the central stimulating effect on the activity of the sympathetic nervous system [49]. The kidneys are involved in the process. Studies have shown a clear association between circulating leptin levels and enhanced renal sympathetic stimulation [50], which was accompanied under experimental conditions by increased secretion of renin, and enhanced sodium and water reabsorption in the proximal tubule [51]. Despite that, the association between $\mathrm{AH}$ and obesity may be explained by the presence of IR and hyperinsulinemia [52]. In this study, we have shown a statistically significant association between blood leptin levels and IR in both men and women.

However, it is important to note that genetic factors influences the metabolism of leptin. For example, the 3' UTR and Gln223Arg polymorphism of the leptin receptor were shown to play a role in the development of hyperleptinemia and $\mathrm{AH}[53,54]$. Furthermore, impairment of $\beta$ adrenergic receptor function, as well as G protein and calcium/calmodulin-dependent kinase IV play a role in the development of IR [21,55-57]. Unfortunately, we were unable to investigate the role of those genes in our study.

\section{Conclusion}

Obviously, leptin as a biomarker for body fat reflects a yet unexplored activity of adipocytes and can provide important information regarding the risk of cardiovascular disease [58]. The results of our study show that leptin is associated with general and abdominal obesity, dyslipidemia, and IR. At the same time, further large-scale prospective studies are in great demand to better understand and closely investigate the physiological and pathological functions of leptin.

\section{Abbreviations \\ $\mathrm{AH}$ : Arterial hypertension; AO: Abdominal obesity; BMI: Body mass index; CHD: Coronary heart disease; DBP: Diastolic blood pressure; DM: Diabetes mellitus; HC: Hip circumference; HDL-C: High density cholesterol; IR: Insulin resistance; LDL-C: Low density cholesterol; MS: Metabolic syndrome; SBP: Systolic blood pressure; TC: Total cholesterol; TG: Triglycerides; WC: Waist circumference.}

\section{Competing interests}

The authors declare that they have no competing interests.

\section{Authors' contributions}

All authors contributed equally during the investigation process and article writing. All authors participated in manuscript discussion. All authors have read and approved the final manuscript. AEM performed English translation and revision of the manuscript.

\section{Acknowledgment}

This study was conducted with support of Dir adjoint du département Hommes, Natures, Musée de l'Homme (Paris, France). We acknowledge and express our sincere gratitude for the help in analyzing this study.

Received: 9 January 2014 Accepted: 20 June 2014 Published: 30 June 2014

\section{References}

1. Global Status Report on non-communicable diseases 2010. Edited by Alwan A. WHO; 2011:164. Available on http://whqlibdoc.who.int/ publications/2011/9789240686458_eng.pdf?ua=1.

2. Santulli G: Epidemiology of cardiovascular disease in the 21st century: updated numbers and updated facts. JCVD 2013, 1:1-2.

3. Santulli G: Coronary heart disease risk factors and mortality. JAMA 2012, 307(11):1137.

4. Jensen MD, Ryan DH, Apovian CM, Loria CM, Ard JD, Millen BE, Comuzzie AG, Nonas CA, Donato KA, Pi-Sunyer FX, Hu FB, Stevens J, Hubbard VS, Stevens VJ, Jakicic JM, Wadden TA, Kushner RF, Wolfe BM, Yanovski SZ: AHA/ACC/TOS guideline for the management of overweight and obesity in adults. JACC 2013, 2013: doi:10.1016/j.jacc.2013.11.004.

5. Pi-Sunyer FX: The epidemiology of central fat distribution in relation to disease. Nutr Rev 2004, 62:S120-S126.

6. Meier U, Gressner AM: Endocrine regulation of energy metabolism: review of pathobiochemical and clinical aspects of leptin, ghrelin, adiponectin, and resistin. Clin Chem 2004, 50:1511-1525.

7. Zhang Y, Proenca R, Maffei M, Barone M, Leopold L, Friedman JM: Positional cloning of the mouse obese gene and its human homologue. Nature 1994, 372:425-432.

8. Considine RV, Sinha MK, Heiman ML, Kriauciunas A, Stephens TW, Nyce MR, Ohannesian JP, Marco CC, McKee LJ, Bauer TL, Caro JF: Serum immunoreactive-leptin concentrations in normal-weight and obese humans. N Engl J Med 1996, 334:292-295.

9. Haynes WG: Role of leptin in obesity-related hypertension. Exp Physiol 2005, 90:683-688.

10. Zuo H, Shi Z, Yuan B, Dai Y, Wu G, Hussain A: Association between serum leptin concentrations and insulin resistance: a population-based study from China. PLoS One 2013, 8(1):e54615. doi:10.1371/journal.pone.0054615.

11. Kim K, Valentine RJ, Shin Y, Gong K: Associations of visceral adiposity and exercise participation with C-reactive protein, insulin resistance, and endothelial dysfunction in Korean healthy adults. Metabolism 2008, 57 (9):1181-9. doi:10.1016/j.metabol.2008.04.009.

12. Abu-Farha M, Behbehani K, Elkum N: Comprehensive analysis of circulating adipokines and hsCRP association with cardiovascular disease risk factors and metabolic syndrome in Arabs. Cardiovasc Diabetol 2014, 13(1):76. doi:10.1186/1475-2840-13-76.

13. Babusik P, Duris I: Comparison of obesity and its relationship to some metabolic risk factors of atherosclerosis in Arabs and south Asians in Kuwait. Med Princ Pract 2010, 19:275-280.

14. Gill PS, Kai J, Bhopal RS, Wild S: Healthcare needs assessment. Black and minority ethnic groups. http://hcna.radcliffe-oxford.com/bemgframe.htm.

15. Kannel WB, Hjortland M, Castelli WP: Role of diabetes in congestive heart failure: the Framingham study. Am J Cardiol 1974, 34:29-34.

16. Stefan N, Fritsche A, Haring HU: Insulin resistance and congestive heart failure. JAMA 2005, 294:334-341.

17. Kenchaiah S, Evans JC, Levy D, Wilson PW, Benjamin EJ, Larson MG, Kannel WB, Vasan RS: Obesity and the risk of heart failure. N Engl J Med 2002, 347:305-313.

18. National Center for Health Statistics: Health United States 2003 with chart book on trends in the health of Americans. Hyattsville, MD: U.S. Department of Health and Human services Centers for Disease Control and Prevention National Center for Health Statistics; 2003:26-31. http://www.cdc.gov/nchs/ data/hus/hus03.pdf.

19. Grundy SM, Cleeman JI, Daniels SR, Donato KA, Eckel RH, Franklin BA, Gordon DJ, Krauss RM, Savage PJ, Smith SC Jr, Spertus JA, Costa F: Diagnosis and management of the metabolic syndrome: an American heart association/national heart, lung and blood institute scientific statement. Curr Opin Cardiol 2006, 21:1-6.

20. Lindstrom J, Tuomilehto J: The diabetes risk score: a practical tool to predict type 2 diabetes risk. Diabetes Care 2003, 26:725-731. 
21. Mirrakhimov AE, Kerimkulova AS, Lunegova OS, Moldokeeva CB, Zalesskaya YV, Abilova SS, Sovhozova NA, Aldashev AA, Mirrakhimov EM: An association between Trp64Arg polymorphism of the b3 adrenoreceptor gene and some metabolic disturbances. Cardiovasc Diabetol 2011, 10:89.

22. Friedewald WT, Levy RI, Fredrickson DS: Estimation of the concentration of low density lipoprotein cholesterol in plasma, without use of the preparative ultracentrifuge. Clin Chem 1972, 18:499-502

23. Hu FB, Chen C, Wang B, Stampfer MJ, Xu X: Leptin concentrations in relation to overall adiposity, fat distribution, and blood pressure in a rural Chinese population. Int J Obes Relat Metab Disord 2001 25:121-125.

24. Bennett Fl, McFarlane-Anderson N, Wilks R, Luke A, Cooper RS, Forrester TE: Leptin concentration in women is influenced by regional distributi on of adipose tissue. Am J Clin Nutr 1997, 66:1340-1344.

25. Havel PJ, Kasim-Karakas S, Dubuc OR, Mueller W, Phinney SD: Gender differences in plasma leptin concentrations. Nat Med 1996, 2:949-950.

26. Rosenbaum M, Nicolson M, Hirsch J, Heymsfield SB, Gallagher D, Chu F, Leibel RL: Effects of gender, body composition, and menopause on plasma concentrations of leptin. J Clin Endocrinol Metab 1996, 81:3424-3427.

27. Sheu WH, Lee WJ, Chen YT: High plasma leptin concentrations in hypertensive men but not in hypertensive women. J Hypertens 1999, 17:1289-1295.

28. Krotkiewski M, Bjorntorp P, Sjostrom L, Smith U: Impact of obesity on metabolism in men and women. Importance of regional adipose tissue distribution. J Clin Invest 1983, 72:1150-1162.

29. Minocci A, Savia G, Lucantoni R, Berselli ME, Tagliaferri M, Calo G, Petroni ML, de Medici C, Viberti GC, Liuzzi A: Leptin plasma concentrations are dependent on body fat distribution in obese patients. Int J Obes 2000 24:1139-1144.

30. Kotani K, Tokunaga K, Fujioka S, Kobatake T, Keno Y, Yoshida S, Shimomura I, Tarui S, Matsuzawa Y: Sexual dimorphism of age-related changes in whole-body fat distribution in the obese. Int J Obes Relat Metab Disord 1994, 18:207-210.

31. Ingelsson E, Larson MG, Yin X, Wang TJ, Meigs JB, Lipinska I, Benjamin EJ, Keaney JF Jr, Vasan RS: Circulating ghrelin, leptin, and soluble leptin receptor concentrations and cardiometabolic risk factors in a community-based sample. J Clin Endocrinol Metab 2008, 93:3149-3157.

32. Kennedy A, Gettys TW, Watson P, Wallace P, Ganaway E, Pan Q, Garvey WT: The metabolic significance of leptin in humans: gender-based differences in relationship to adiposity, insulin sensitivity, and energy expenditure. J Clin Endocrinol Metab 1997, 82:1293-1300.

33. Jockenhovel F, Blum WF, Vogel E, Englaro P, Müller-Wieland D, Reinw ein D, Rascher W, Krone W, Reinwein D, Rascher W, Krone W: Testosterone substitution normalizes elevated serum leptin levels in hypogonadal men. J Clin Endocrinol Metab 1997, 82:2510-2513.

34. Haluzik M, Fiedler J, Nedvidkova J, Ceska R: Serum leptin levels in patients with hyperlipidemias. Nutrition 2000, 16:429-433.

35. Al-Shoumer KA, Anyaoku V, Richmond W, Johnston DG: Elevated leptin concentrations in growth hormone-deficient hypopituitary adults. Clin Endocrinol 2000, 47:153-159.

36. Rainwater DL, Comuzzie AG, VandeBerg JL, Mahaney MC, Blangero J: Serum leptin levels are independently correlated with two measures of HDL. Atherosclerosis 1997, 32:237-243.

37. Chapman IM, Wittert GA, Norman RJ: Circulating leptin concentrations in polycystic ovary syndrome: relation to anthropometric and metabolic parameters. Clin Endocrinol 1997, 46:175-181.

38. Leyva F, Godsland IF, Ghatei M, Proudler AJ, Aldis S, Walton C, Bloom S, Stevenson JC: Hyperleptinemia as a component of a metabolic syndrome of cardiovascular risk. Arterioscler Thromb Vasc Biol 1998, 18:928-933.

39. Rosenbaum M, Leibel RL: Pathophysiology of childhood obesity. Adv Pediatr 1988, 35:73-137.

40. Rosenbaum M, Leibel RL: The role of leptin in human physiology. N Engl J Med 1999, 341:879-884.

41. Comizio R, Pietrobelli A, Tan YX, Wang Z, Withers RT, Heymsfield SB, Boozer $C N$ : Total body lipid and triglyceride response to energy deficit: relevance to body composition models. Am J Physiol 1998, 274:860-866.

42. Barba G, Russo O, Siani A, lacone R, Farinaro E, Gerardi MC, Russo P, Della Valle E, Strazzullo P: Plasma leptin and blood pressure in men: graded association independent of body mass and fat pattern. Obes Res 2003, 11:160-166
43. Shek EW, Brands MW, Hall JE: Chronic leptin infusion increases arterial pressure. Hypertension 1998, 31:409-414.

44. Aizawa-Abe M, Ogawa Y, Masuzaki H, Ebihara K, Satoh N, Iwai H, Matsuoka N, Hayashi T, Hosoda K, Inoue G, Yoshimasa Y, Nakao K: Pathophysiological role of leptin in obesity-related hypertension. J Clin Invest 2000, 105:1243-1252.

45. Paolisso G, Tagliamonte MR, Galderisi M, Zito GA, D'Errico A, Marfella R, Carella C, de Divitiis O, Varricchio M: Plasma leptin concentration, insulin sensitivity, and 24-hour ambulatory blood pressure and left ventricular geometry. Am J Hypertens 2001, 14:114-120.

46. Matsui H, Yokoyama T, Tanaka C, Sunaga H, Koitabashi N, Takizawa T, Arai M, Kurabayashi M: Pressure mediated hypertrophy and mechanical stretch up-regulate expression of the long form of leptin receptor (ob-Rb) in rat cardiac myocytes. BMC Cell Biol 2012, 27:13-37.

47. Grassi G, Colombo M, Sevalle G, Spaziani D, Manci G: Dissociation between muscle and skin sympathetic activity in essential hypertension, obesity, and congestive heart failure. Hypertension 1998, 31:64-67.

48. Vaz M, Jennings G, Turner A, Cox H, Lambert G, Esler M: Regional sympathetic nervous activity and oxygen consumption in obese normotensive human subjects. Circulation 1997, 96:3423-3429.

49. Rahmouni K, GHaynes W: Leptin and the central neural mechanisms of obesity hypertension. Drugs Today (Barc) 2002, 38(12):807-17.

50. Eikelis N, Esler M: The neurobiology of human obesity. Exp Physiol 2005 90:673-682.

51. Bonora E, Kiechl S, Willeit J, Oberhollenzer F, Egger G, Targher G, Alberiche $M$, Bonadonna RC, Muggeo M: Prevalence of insulin resistance in metabolic disorders: the Bruneck Study. Diabetes 1998, 47:1643-1649.

52. Reaven GM, Lithell H, Landsberg L: Hypertension and associated metabolic abnormalities - the role of insulin resistance and the sympathoadrenal system. The New Engl J of Med 1996, 334(6):374-381.

53. Gu P, Jiang W, Chen M, Lu B, Shao J, Du H, Jiang S: Association of leptin receptor gene polymorphisms and essential hypertension in a Chinese population. J Endocrinol Investig 2012, 35(9):859-865.

54. Nagalingam S, Uppuluri MV, Gunda P, Ravishanker U, Tirunilai P. Evaluation of leptin and leptin receptor gene 30 UTR polymorphisms in essential hypertension. Clin Exp Hypertens. Early Online: 1-7, doi:10.3109/10641963.2013.846356

55. Mirrakhimov EM, Lunegova OS, Mirrakhimov AE, Kerimkulova AS, Starov N, Abilova SS, Zalesskaya YV, Alibaeva NT, Aldashev AA: Frequency of the C825T polymorphism of the $G$ protein $\beta_{3}$ subunit and its association with obesity in the Kyrgyz population. Family medicine and community health 2013, 1(1):23-29.

56. Santulli G, Cipolletta E, Sorriento D, Del Giudice C, Anastasio A, Monaco S, Maione AS, Condorelli G, Puca A, Trimarco T, Illario M, laccarino G: CaMK4 gene deletion induces hypertension. J Am Heart Assoc 2012, 1(4):e001081.

57. Cipolletta E, Campanile A, Santulli G, Sanzari E, Leosco D, Campiglia P, Trimarco B, laccarino $G$ : The $G$ protein coupled receptor kinase 2 plays an essential role in beta-adrenergic receptor-induced insulin resistance. Cardiovasc Res 2009, 84(3):407-415.

58. Wallace AM, McMahon AD, Packard CJ, Kelly A, Shepherd J, Gaw A, Sattar N: Plasma leptin and the risk of cardiovascular disease in the west of Scotland coronary prevention study (WOSCOPS). Circulation 2001, 104:3052-3056.

doi:10.1186/1756-0500-7-411

Cite this article as: Mirrakhimov et al:: The association of leptin with dyslipidemia, arterial hypertension and obesity in Kyrgyz (Central Asian nation) population. BMC Research Notes 2014 7:411. 